\title{
Evaluation of serum levels of copper and selenium in Helicobacter pylori positive and negative gastritis patients
}

\author{
Vahid Hamidi OMRAN ${ }^{1}$ (i), Mohammad RANAEI ${ }^{2,3}$ (D), Nahid NEAMATI ${ }^{4,5}$, Javad Shokri Shirvani ${ }^{3}$, Karimolah

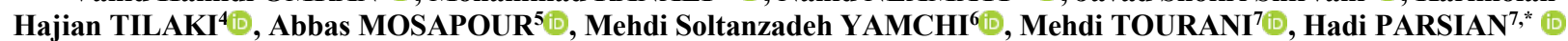 \\ ${ }^{1}$ Student Research Committee, Babol University of Medical Sciences, Babol, Iran \\ ${ }^{2}$ Department of Pathology, Rouhani Hospital, Babol University of Medical Sciences, Babol, Iran \\ ${ }^{3}$ Cancer Research Center, Health Research Institute, Babol University of Medical Sciences, Babol, Iran \\ ${ }^{4}$ Social Determinants of Health Research Center, Health Research Institute, Babol University of Medical Sciences, Babol, Iran \\ ${ }^{5}$ Department of Clinical Biochemistry, School of Medicine, Babol University of Medical Sciences, Babol, Iran \\ ${ }^{6}$ Immunoregulation Research Center, Health Research Institute, Babol University of Medical Sciences, Babol, Iran \\ ${ }^{7}$ Cellular and Molecular Biology Research Center, Health Research Institute, Babol University of Medical Sciences, Babol, Iran
}

\begin{abstract}
Received: 16.05 .2020
Accepted/Published Online: 20.11 .2020

Final Version: 14.03 .2021

Abstract

Helicobacter pylori (H. pylori) infection can result in various complications, included micronutrient variations, nutritional impairment, gastric tissue damages and oxidative stress. The present study aimed to evaluate serum variations of $\mathrm{Cu}$ and Se in $H$. pylori infected individuals. A prospective case-control study was performed on 69 participants with abdominal pains (40 patients with H. pylori gastritis versus 29 control group). Serum levels of $\mathrm{Cu}$ and Se were measured using Atomic Absorption Spectrophotometer. Statistical analysis was performed using SPSS software. Comparisons of elements between included groups were done using independent sample t-test. Subgroup analysis between male and female (with or without $H$. pylori) was performed using one way analysis of variance. Correlation between serum $\mathrm{Cu}$ and Se was assessed using Pearson's correlation test. The p-value levels less than 0.05 were considered as significant. There were no significant differences in serum levels of $\mathrm{Cu}$ and Se between $H$. pylori positive and negative persons. In male with $H$. pylori, Se levels were $38.4 \%$ higher than control male (p-value $=0.03$ ). A positive and significant correlation was observed between serum $\mathrm{Cu}$ and $\mathrm{Se}$ levels $(\mathrm{r}=0.51, \mathrm{P}$-value $=0.024)$. Although no statistic difference was observed in serum $\mathrm{Cu}$ and Se levels, the significant correlation between measured elements represents as good evidence for some discrepancies. Given the importance of well controlled micronutrients in whole body health, especially in high-risk $H$. pylori patients, more studies are needed to clarify the exact relation of these and other trace elements with $H$. pylori outcomes.
\end{abstract}

Keywords: Copper, gastroduodenal complication, helicobacter pylori, selenium

\section{Introduction}

Gastroduodenal diseases are the cause of a wide range of complications, such as chronic gastric diseases, systemic inflammation and carcinoma (Kusters et al., 2006). Many studies have attributed these diseases to infection with Helicobacter pylori (H. pylori), a microaerophilic gramnegative flagellated spiral-shaped bacteria (Kusters et al., 2006). Epidemiological evidences indicated a high prevalence of $H$. pylori infection, worldwide. Infection with this bacterium has been reported in more than 50 percent of the world's population, especially in developing countries and nearly 70 percent of the Iranian population (Eshraghian, 2014; Peleteiro et al., 2014; Rezaeimehr et al., 2016). The prevalence studies in north Iran has been shown that women are most likely to be infected with $H$. pylori than men $(73.7 \%$ vs. $68.7 \%$, respectively) (Ghadimi et al., 2007).

Despite the presence of many proposed therapeutic strategies for the treatment and improvement of patients with H. pylori infection, the high prevalence of this infection, is the best evidence for survival of the bacteria in the gastric tissue of most infected individuals. Bacterial localization in the gastric mucosa is known as one of the most common causes of gastritis. Chronic gastritis, ulcerative disease, colon cancer, type B low grade mucosal-associated lymphoma and gastric adenocarcinoma are the probable consequences of infection with H. pylori (Kusters et al., 2006; Teimoorian et al., 2018). 
Another property attributed to $H$. pylori infection is production of free reactive oxygen and nitrogen species, resulting oxidative stress damage in the host tissue cells (Ding et al., 2007; Butcher et al., 2017). The oxidative stress status may be due to the involvement of the host immune response induced by $H$. pylori infection or through the presence of bacteria in the gastric tissue and production of anionic superoxide radicals or resulted from cytotoxins that released by H. pylori in the gastric epithelial cells (Naito and Yoshikawa, 2002; Ding et al., 2007; Butcher et al., 2017). Oxidative stress, regardless of its causative agent, can lead to oxidative damages to DNA and oncogenic outcomes.

Intracellular superoxide dismutase $(\mathrm{Zn} / \mathrm{Cu}-\mathrm{SOD})$ activity is considered as one of the most important mechanism involved in detoxification of superoxide radicals. In addition to superoxide dismutase, catalase and glutathione peroxidase serves as crucial enzymes involved in the maintenance of the oxidative balance and prevention of the cells against oxidative damages (Dovhanj et al., 2010). Copper ( $\mathrm{Cu}$ ) and Zinc $(\mathrm{Zn})$ are considered as essential trace elements mainly incorporate for maintenance of the oxidative equilibrium status (Florianczyk, 2008). $\mathrm{Cu}$ is mainly found in the ceruloplasmin structure, involved in iron hemostasis, and is also act as cofactor of many enzymes such as cytochrome oxidase, mono-amine oxidase and superoxide dismutase (Yakoob et al., 2003; Florianczyk, 2008).

Selenium (Se) is another essential trace element in many of the redox reactions, as well as the human immune system. In the form of selenocysteine, it is found in the structure of various selenoproteins such as glutathione peroxidase. Se deficiency may result in various complications such as oxidative stress impairment, immune response disorders, susceptibility to infection, malignancies and etc. (Gromer et al., 2005; Hoffmann and Berry, 2008).

Given the importance of the assessment and maintenance of the normal levels of the micronutrients, we aimed to evaluate $\mathrm{Cu}$ and $\mathrm{Se}$ levels in the serum of $H$. pylori infected individuals compared with control group.

\section{Materials and methods}

\subsection{Study design and sample preparation}

A prospective case-control study was performed on 40 patients with $H$. pylori gastritis referring to Gastroenterology Department of Ayatollah Rouhani Hospital (Babol University of Medical Sciences, Babol, Iran). The patients were diagnosed based on clinical manifestation, endoscopy, results of pathological examination, serum antibodies against $H$. pylori as well as rapid urease test. Participants' information including age, sex, and types of the diagnosis were extracted and included in the study. Twenty-nine subjects, who had been referred to the hospital with abdominal pains, undergoing clinical and endoscopic examination, but no diagnosis of gastritis and any type of malignancy, were included as control group.
Individuals with a history of malignancy, patients who were undergoing the treatment, individuals with a history of inflammation or any other specific disease, as well as those who were previously taken medications to treat the symptoms of the disease, were excluded. The present study protocol received institutional and approved by ethical committee of Babol University of Medical Sciences (code 4182) and a written informed consent was obtained from that all participants in the format required by the ethical committee.

For measurement of the serum levels of copper $(\mathrm{Cu})$ and selenium (Se), fasting blood sampling performed from all participants at the morning. Separation of serum from whole blood was done with a centrifugation at $2500 \mathrm{~g}$ for 10 minutes and serum samples were stored at $-80^{\circ} \mathrm{C}$ until analysis. Measurement of serum levels of $\mathrm{Cu}$ and Se were done using Atomic Absorption Spectrophotometer with Graphic Furnace Power Supply (PG 990, PG Instruments Ltd., China).

\subsection{Atomic absorption method for evaluation of serum $\mathrm{Cu}$ and Se status}

Serum $\mathrm{Cu}$ level was measured by preparing different concentrations of $\mathrm{CuSO}_{4}$ (Merck, Germany) as $\mathrm{Cu}$ standards (i.e., 5, 10, 20, 40 and $50 \mathrm{ppb}$ ) using $0.5 \mathrm{M} \mathrm{HNO}_{3}$ as diluent. The serum samples were diluted to $1: 20$ with $0.1 \mathrm{M} \mathrm{HNO}_{3}$ and $10 \mu \mathrm{l}$ of the diluted sample were injected into graphite furnace and the levels were reported according to the standard curve. The analytical parameters were determined for measuring serum $\mathrm{Cu}$ levels including $324.7 \mathrm{~nm}$ wavelength, $0.4 \mathrm{~nm}$ bandwidth and $3 \mathrm{~mA}$ lamp current. Thermal cycle for analysis of $\mathrm{Cu}$ is presented in Table 1.

Table 1. Atomic absorption spectrophotometry settings and furnace program for $\mathrm{Cu}$ and $\mathrm{Se}$ analysis.

\begin{tabular}{|lllll}
$\begin{array}{l}\text { Step } \\
\text { Unit }\end{array}$ & $\begin{array}{l}\text { Temperature } \\
\left({ }^{\circ} \mathbf{C}\right) \\
(\mathbf{C u}-S e)\end{array}$ & $\begin{array}{l}\text { Ramp } \\
(\text { second) } \\
(\mathbf{C u}-\mathbf{S e})\end{array}$ & $\begin{array}{l}\text { Hold } \\
(\mathbf{s e c o n d}) \\
(\mathbf{C u}-\mathbf{S e})\end{array}$ & $\begin{array}{l}\text { Argon } \\
\mathbf{f l o w} \\
(\mathbf{m l} / \mathbf{m i n}) \\
(\mathbf{C u}-\mathbf{S e})\end{array}$ \\
\hline Drying & $70-110$ & $5-10$ & $10-10$ & $300-300$ \\
Drying & $110-230$ & $10-10$ & $10-5$ & $300-300$ \\
Pyrolsis & $600-1000$ & $10-10$ & $15-20$ & $300-300$ \\
Atomization & $2100-2100$ & $0-0$ & $3-3$ & $0-0$ \\
Clean up & $2200-2300$ & $1-1$ & $2-2$ & $300-300$
\end{tabular}

In order to measurement of the serum status of Se, various $\mathrm{SeO}_{2}$ dilutions (i.e., 12.5, 25, 50 and $100 \mathrm{ppb}$ ) were used as standards and $0.1 \mathrm{M} \mathrm{HNO}_{3}$ served as diluent. Determination of Se level was done by diluting of the serum to a ratio of $1: 2$ with $0.1 \mathrm{M} \mathrm{HNO}_{3}$ and ultimately $10 \mu \mathrm{l}$ of the diluted sample was injected into graphite furnace. The analytical parameters related to Se measurements, were a wavelength of $196 \mathrm{~nm}$, a $0.4 \mathrm{~nm}$ bandwidth, and a $5 \mathrm{~mA}$ lamp current. Thermal cycle for analysis of Se is presented in Table 1.

\subsection{Statistical analysis}

Analysis of the measured data was performed using SPSS software (version 25, SPSS Inc., Chicago, IL, USA). Normal distribution of variables was evaluated using Kolmogorov- 
Smirnov test. Independent sample t-test was used for comparison of serum levels of $\mathrm{Cu}$ and $\mathrm{Se}$ among included subgroups. The correlation between serum $\mathrm{Cu}$ and $\mathrm{Se}$ in study groups was assessed using Pearson's correlation test. The pvalue levels less than 0.05 were considered as significant.

Table 2. Serum levels of trace elements in included groups

\begin{tabular}{|cccc|} 
& $\begin{array}{c}\text { H. pylori pos. } \\
(\mathbf{n}=\mathbf{4 0})\end{array}$ & $\begin{array}{c}\text { H. pylori neg. } \\
(\mathbf{n}=\mathbf{2 9})\end{array}$ & $\mathbf{P}$ \\
\hline $\mathbf{C u}(\mathbf{p p b})$ & $62.81 \pm 17.73$ & $61.68 \pm 12.97$ & 0.772 \\
Se (ppb) & $49.77 \pm 16.37$ & $45.36 \pm 16.61$ & 0.277 \\
\hline
\end{tabular}

$\mathrm{Cu}$ : Copper; Se: Selenium

As Table 2 shows, there are not significant differences between analyzed trace elements in $H$. pylori positive and negative persons. Categorization of the resulted data in included participants according to gender is presented in Table 3 .

Table 3. Serum levels of trace elements in included groups and subgroups

\begin{tabular}{|c|c|c|c|c|c|c|}
\hline & \multicolumn{2}{|c|}{ Male } & \multirow[b]{2}{*}{$\mathbf{P}$} & \multicolumn{2}{|c|}{ Female } & \multirow[t]{2}{*}{$\mathbf{P}$} \\
\hline & $\begin{array}{c}\text { H. pylori } \\
\text { pos. } \\
(\mathrm{n}=19)\end{array}$ & $\begin{array}{c}\text { H. pylori } \\
\text { neg. } \\
(\mathrm{n}=9)\end{array}$ & & $\begin{array}{c}H . \\
\text { pylori } \\
\text { pos. } \\
(\mathrm{n}=\mathbf{2 1})\end{array}$ & $\begin{array}{c}H . \\
\text { pylori } \\
\text { neg. } \\
(\mathrm{n}=\mathbf{2 0})\end{array}$ & \\
\hline $\begin{array}{c}\mathrm{Cu} \\
(\mathrm{ppb})\end{array}$ & $\begin{array}{c}60.2 \pm 1 \\
7.5\end{array}$ & $63.1 \pm 12.4$ & 0.661 & $65.1 \pm 17.9$ & $61.0 \pm 13.5$ & 0.994 \\
\hline $\begin{array}{c}\mathrm{Se} \\
(\mathrm{ppb})\end{array}$ & $\begin{array}{c}50.7 \pm \\
16.4\end{array}$ & $37.4 \pm 10.1$ & $\begin{array}{c}0.035 \\
*\end{array}$ & $48.9 \pm 16.7$ & $48.9 \pm 17.9$ & 0.415 \\
\hline
\end{tabular}

$\mathrm{Cu}$ : Copper; Se: Selenium. *: P-value less than 5\%

\section{Results}

In this case-control, cross sectional study 69 persons participated who were stratified in two separate groups of 40 patients $(42.0 \pm 9.4$ years old, female $=21$ and male $=19)$ and 29 control group $(44.4 \pm 11.2$ years old female $=20$ and male $=9)$. The status of serum trace elements levels is presented in Table 2.

As it is clear from this table, there are no significant differences among trace elements in groups. An exception was related to Se levels which were $38.4 \%$ higher in male participants with $H$. pylori infection compared with control male $(p=0.035)$. The correlations between $\mathrm{Cu}$ and $\mathrm{Se}$ in included groups were analyzed. In male participants with $H$. pylori infection, a positive and significant correlation between serum $\mathrm{Cu}$ and Se levels $(\mathrm{r}=0.52, \mathrm{p}=0.020)$ was observed (Fig. 1).

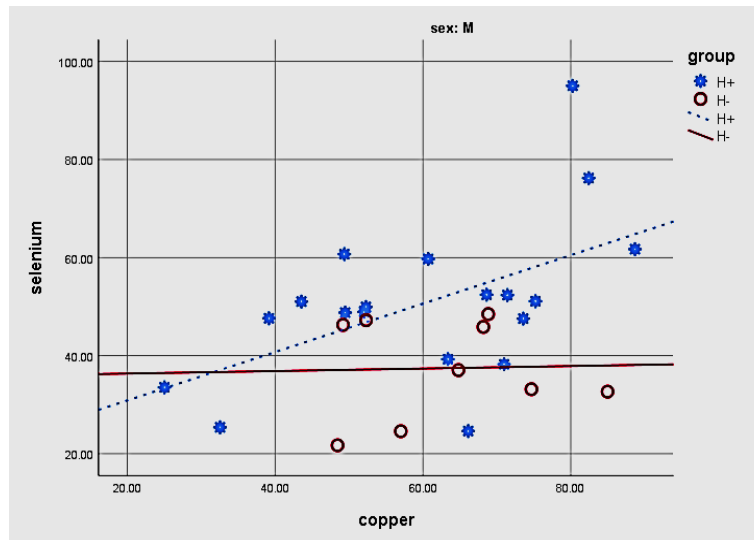

Fig. 1. Correlation between serum $\mathrm{Cu}$ and $\mathrm{Se}$ in male participants with H. pylori $(\mathrm{r}=0.52 ; \mathrm{p}$-value $=0.020)$

\section{Discussion}

In the present study, the relationship between $H$. pylori infection and the levels of $\mathrm{Cu}$ and $\mathrm{Se}$ trace elements were evaluated and compared with control group. As main result, no statistic difference was observed in serum $\mathrm{Cu}$ and $\mathrm{Se}$ among included groups. In addition, a significant correlation was observed in $\mathrm{Cu}$ and Se levels in patients with $H$. pylori infection; but such a correlation was not observed in control group. According to the results, $38.4 \%$ increase in level of Se was observed in male with $H$. pylori infection compared with control male participants.

H. pylori infection is accounted as a well-established risk factor for some gastrointestinal complications such as malnutrition, acute and chronic gastritis, and gastrointestinal malignancies (Kusters et al., 2006). Bacterial infection which is initiates with colonization in the gastric mucosa can lead to active gastritis and also is the cause of several inflammatory processes (Kao et al., 2016; Sayar et al., 2019). The subsequence outcomes by the $H$. pylori induced inflammation are affected by bacterial and host characteristic factors, for instance, strain of $H$. pylori colonization and individual characteristics of the host such as genetics, immune responsibility, life style and gastric acidity. According to some reports, severe inflammation without treatment will be accounted as the cause of gastric ulcerative diseases, lymphoma and gastric cancer (Polk and Peek Jr, 2010; Kao et al., 2016; Sayar et al., 2019).

The pathogenesis of $H$. pylori may be attributed to involvement of the innate immune cells and release of some inflammatory factors those are produced against the bacteria. Neutrophil and macrophage respiratory burst, as well as the production of free reactive oxygen and nitrogen species by gastric epithelial cells can provide a cytotoxic environment for inhibition of the bacterial growth (Naito and Yoshikawa, 2002; Handa et al., 2011). On the other hand, superoxide anions which are by products of bacterial respiratory chain reactions can be effective in prevention of bactericidal effects on some inflammatory products of the host immune cells such as nitric oxide (Nagata et al., 1998).

In many studies there is a significant correlation between H. pylori infection and increased oxidative stress biomarkers (Ding et al., 2007; Butcher et al., 2017). However, human have some enzymatic complex such as catalase, superoxide dismutase and glutathione peroxidase which are responsible for maintenance of the balanced reactive oxygen species against unwanted effects of oxidative damages to the host tissue cells (Mori et al., 1997). $\mathrm{Cu} / \mathrm{Zn}$ superoxide dismutase, a metal dependent enzyme, has a critical function on the regulation of oxidative balance in the host tissues. Götz et al. proposed that $H$. pylori infection has influences on the activity of some enzymes (such as superoxide dismutase) which are involved in metabolism of free reactive oxygen species (Götz et al., 1997). 
There are strong evidences about toxicity effects of metal overloaded in bacterial environment. H. pylori is equipped with some specialized metal transporter systems such as CznABC transport system and ATP cation transporter which are corporate in $\mathrm{Cu}$ and $\mathrm{Zn}$ removing from bacteria (Stähler et al., 2006). Some H. pylori strains have a type of cationic membrane transporter, by product of cop $A$ gene, serves as $\mathrm{Cu}$ exporter to the outer environment of the bacteria and maintain the $\mathrm{Cu}$ homeostasis, that is essential for the growth and survival of the bacteria (Ge and Taylor, 1996). In addition, it has been shown that $\mathrm{Cu}$ can modulate formation of trefoil factor family (TFF1) homodimer, a type of peptide that is responsible for the regeneration of the epithelial cells of the gastrointestinal tract, by binding to the carboxy-terminal of the TFF1 (Montefusco et al., 2013). H. pylori by binding to the TFF1 dimer form can induce gastric carcinogenesis. In this way, $H$. pylori can be effective in SOD activity and also variations of $\mathrm{Cu}$ level in human (Montefusco et al., 2013). Ustundag et al. reported no difference in serum Se levels between H. pylori infected patients and control group, but tissue accumulation of Se in patients with $H$. pylori those suffer from mild and severe gastritis is in favor of prevention gastric carcinogenesis (Üstündag et al., 2001). Nezhad et al. reported the linkage between lower Se levels and risk of gastric cancer (Nezhad et al., 2015). Cai et al. reported that Se exposure can be beneficial for prevention of some malignancies such as breast, lung, esophagus and gastric cancer (Cai et al., 2016). In the previous studies, no significant difference in Se levels was reported between $H$. pylori infected patients compared with control group (Cai et al., 2016). However, with consideration of its potential antioxidant properties as well as its efficacy in promotion of human immune system, Wu et al. proposed after H. pylori eradication, decrease in Se level is a good evidence for preservative effect of Se against $H$. pylori infection (Wu et al., 2014). In the present study, higher but no significant Se level, was observed among patients with $H$. pylori gastritis; however, a significant positive correlation observed between $\mathrm{Se}$ and $\mathrm{Cu}$ levels among male participants with $H$. pylori. It may be resulted by the presence of bacterial cation exporting channels as well as inflammatory responses of host immune system.

Decreased serum levels of $\mathrm{Cu}, \mathrm{Zn}$ and $\mathrm{Fe}$ have been reported in serum sample of pregnant women with $H$. pylori infection (Ugwuja and Akubugwo, 2010). Öztürk et al. reported a decrease (but non-significant levels) of $\mathrm{Cu}$ in serum sample of children with $\mathrm{H}$. pylori infection (Ozturk et al., 2015). In addition, increased levels of serum $\mathrm{Zn}$ as well as no difference in serum Se levels were observed in this study (Ozturk et al., 2015). No significant difference of $\mathrm{Cu}$ levels has been reported in most of the researches (Hacibekiroglu et al., 2015; $\mathrm{Hu}$ et al., 2018). Increased serum level of $\mathrm{Cu}$ was reported by Janjetic et al. in patients with $H$. pylori infection (Janjetic et al., 2010). Hacibekiroglu et al. refuted any significant association between serum levels of $\mathrm{Fe}, \mathrm{Cu}$ and $\mathrm{Zn}$ with H. pylori antibodies (Hacibekiroglu et al., 2015). Wu et al. reported no significant differences between serum levels of $\mathrm{Zn}$, Se and $\mathrm{Cu}$ in $\mathrm{H}$. pylori infected individuals compared with control subjects. A reasonable justification may be related to absorption impairment that caused by changes in inflammation status in $H$. pylori infected persons. Higher Se concentration after impairment of nutritional absorption may be inducing Zinc deficiency. More studies are needed for understanding the exact correlation between $\mathrm{Zn}$ and $\mathrm{Cu}$ in $\mathrm{H}$. pylori infected patients.

In conclusion, although no significant differences were observed in serum $\mathrm{Cu}$ and Se status among H. pylori infected individuals compared with control subjects, but some discrepancies were observed. As infections are able to induce trace element nutritional absorption impairment in at risk persons, it is recommended that any trace element discrepancy in these patients should be considered as an important outcome.

For the future studies, evaluation and comparison of serum and tissue $\mathrm{Cu}, \mathrm{Se}$ and the other micronutrients is suggested for better understanding the exact correlation of them with $\mathrm{H}$. pylori outcomes

\section{Conflict of Interest}

No conflict of interest was declared by the authors.

\section{Acknowledgements}

The present study was funded by Babol University of Medical Sciences, Babol, Iran (grant number 4182). The authors have also thanked vice chancellor for the approval of this study.

\section{References}

1. Butcher, L.D., den Hartog, G., Ernst, P.B., Crowe, S.E. 2017. Oxidative stress resulting from Helicobacter pylori infection contributes to gastric carcinogenesis. CMGH. 3, 316-322.

2. Cai, X., Wang, C., Yu, W., Fan, W., Wang, S., Shen, N., Wu, P., Li, X., Wang, F. 2016. Selenium exposure and cancer risk: an updated meta-analysis and meta-regression. Sci. Rep. 6, 19213.

3. Ding, S.-Z., Minohara, Y., Fan, X.J., Wang, J., Reyes, V.E., Patel, J., Dirden-Kramer, B., Boldogh, I., Ernst, P.B., Crowe, S.E. 2007. Helicobacter pylori infection induces oxidative stress and programmed cell death in human gastric epithelial cells. Infect. immun. 75, 4030-4039.

4. Dovhanj, J., Kljaic, K., Vcev, A., Ilakovac, V. 2010. Helicobacter pylori and trace elements. Clin. lab. 56, 137-142.

5. Eshraghian, A. 2014. Epidemiology of Helicobacter pylori infection among the healthy population in Iran and countries of the Eastern Mediterranean Region: a systematic review of prevalence and risk factors. World journal of gastroenterology: WJG. 20, 17618.

6. Florianczyk, B. 2008. Trace elements as constituents of antioxidative proteins. Journal of pre-clinical and clinical research. J. Pre. Clin. Clin. Res. 2(1), 25-27.

7. Ge, Z., Taylor, D.E. 1996. Helicobacter pylori genes hpcopA and hpcopP constitute a cop operon involved in copper export. FEMS microbiol. lett. $145,181-188$.

8. Ghadimi, R., Taheri, H., Suzuki, S., Kashifard, M., Hosono, A., Esfandiary, I., Moghadamnia, A.A., Ghadimi, R., Tokudome, S. 2007. Host and environmental factors for gastric cancer in Babol, the Caspian Sea Coast, Iran. Eur. J. Cancer Prev.16, 192-195. 
9. Götz, J., Thio, J., Verspaget, H., Offerhaus, G., Biemond, I., Lamers, C., Veenendaal, R. 1997. Treatment of Helicobacter pylori infection favourably affects gastric mucosal superoxide dismutases. Gut. 40, 591-596.

10. Gromer, S., Eubel, J., Lee, B., Jacob, J. 2005. Human selenoproteins at a glance. Cellular and Molecular Life Sciences CMLS. 62, 24142437.

11. Hacibekiroglu, T., Basturk, A., Akinci, S., Bakanay, S., Ulas, T., Guney, T., Dilek, I. 2015. Evaluation of serum levels of zinc, copper, and Helicobacter pylori IgG and IgA in iron deficiency anemia cases. Eur. Rev. Med. Pharmacol. Sci. 19, 4835-4840.

12. Handa, O., Naito, Y., Yoshikawa, T. 2011. Redox biology and gastric carcinogenesis: the role of Helicobacter pylori. Redox Rep. $16,1-7$.

13. Hoffmann, P.R., Berry, M.J. 2008. The influence of selenium on immune responses. Mol. Nutr. Food Res. 52, 1273-1280.

14. Hu, A., Li, L., Hu, C., Zhang, D., Wang, C., Jiang, Y., Zhang, M., Liang, C., Chen, W., Bo, Q. 2018. Serum Concentrations of 15 Elements Among Helicobacter Pylori-Infected Residents from Lujiang County with High Gastric Cancer Risk in Eastern China. Biol. Trace. Elem. Res. 186(1), 21-30.

15. Janjetic, M.A., Goldman, C.G., Balcarce, N.E., Rua, E.C., González, A.B., Fuda, J.A., Meseri, E.I., Torti, H.E., Barrado, J., Zubillaga, M.B. 2010. Iron, zinc, and copper nutritional status in children infected with Helicobacter pylori. J. Pediatr. Gastroenterol. Nutr. 51, 85-89.

16. Kao, C.Y., Sheu, B.S., Wu, J.J. 2016. Helicobacter pylori infection: An overview of bacterial virulence factors and pathogenesis. Biomed. J. 39, 14-23.

17. Kusters, J.G., van Vliet, A.H., Kuipers, E.J., 2006. Pathogenesis of Helicobacter pylori infection. Clin. Microbiol. Rev. 19, 449-490.

18. Montefusco, S., Esposito, R., D’Andrea, L., Monti, M.C., Dunne, C., Dolan, B., Tosco, A., Marzullo, L., Clyne, M. 2013. Copper promotes TFF1-mediated Helicobacter pylori colonization. PLoS One. 8, e79455.

19. Mori, M., Suzuki, H., Suzuki, M., Kai, A., Miura, S., Ishii, H., 1997. Catalase and superoxide dismutase secreted from Helicobacter pylori. Helicobacter. 2, 100-105.

20. Nagata, K., Yu, H., Nishikawa, M., Kashiba, M., Nakamura, A., Sato, E.F., Tamura, T., Inoue, M., 1998. Helicobacter pylori generates superoxide radicals and modulates nitric oxide metabolism. Journal of Biological Chemistry. 273, 14071-14073.

21. Naito, Y., Yoshikawa, T., 2002. Molecular and cellular mechanisms involved in Helicobacter pylori-induced inflammation and oxidative stress1, 2. Free Radical Biology and Medicine. 33, 323-336.

22. Nezhad, Z.H., Moghaddam, S.D., Zahedi, M.J., Hayatbakhsh, M.,
Sharififar, F., Meimand, F.E., Nazari, M. 2015. Serum selenium level in patients with gastric non-cardia cancer and functional dyspepsia. Iran. J. Med. Sci. 40, 214.

23. Ozturk, N., Kurt, N., Ozgeris, F., Baygutalp, N., Tosun, M., Bakan, N. 2015. Serum zinc, copper, magnesium and selenium levels in children with Helicobacter pylori 'nfection. Eurasian J. Med. 47(2), 126-129.

24. Peleteiro, B., Bastos, A., Ferro, A., Lunet, N. 2014. Prevalence of Helicobacter pylori infection worldwide: A systematic review of studies with national coverage. Dig. Dis. Sci. 59, 1698-1709.

25. Polk, D.B., Peek Jr, R.M. 2010. Helicobacter pylori: Gastric cancer and beyond. Nat. Rev. Cancer. 10, 403.

26. Rezaeimehr, Z., Hosseini, S.R., Darbandi, Z., Hosseini, S.A., Kheirkhah, F., Bijani, A., Bayani, M. 2016. The association between helicobacter pylori infection and cognitive disorder in iranian elderly population. Arch. Clin. Infect. Dis. 11(4), e38193.

27. Sayar, R., Shokri Shirvani, J., Hajian, K., Vosough, Z., Ranaei, M. 2019. The negative association between inflammatory bowel disease and Helicobacter pylori seropositivity. Caspian J. Intern. Med. 10, 217-222.

28. Stähler, F.N., Odenbreit, S., Haas, R., Wilrich, J., Van Vliet, A.H., Kusters, J.G., Kist, M., Bereswill, S. 2006. The novel Helicobacter pylori CznABC metal efflux pump is required for cadmium, zinc, and nickel resistance, urease modulation, and gastric colonization. Infect. Immun. 74, 3845-3852.

29. Teimoorian, F., Ranaei, M., Tilaki, K.H., Shirvani, J.S., Vosough, Z.J.I.j.o.p. 2018. Association of Helicobacter pylori Infection with Colon Cancer and Adenomatous Polyps. Iran. J. Pathol.13(3), 325332 .

30. Ugwuja, E.I., Akubugwo, E.I. 2010. Impact of Maternal Helicobacter pylori Infection on Trace Elements (Copper, Iron and Zinc) and Pregnancy Outcomes. s. Online J. Health Allied. Scs. 8(4), 7.

31. Üstündag, Y., Boyacioglu, S., Haberal, A., Demirhan, B., Bilezikçi, B. 2001. Plasma and gastric tissue selenium levels in patients with Helicobacter pylori infection. J. Clin. Gastroenterol. 32, 405-408.

32. Wu, M.C., Huang, C.Y., Kuo, F.C., Hsu, W.H., Wang, S.S., Shih, H.Y., Liu, C.J., Chen, Y.H., Wu, D.C., Huang, Y.L. 2014. The effect of Helicobacter pylori eradication on the levels of essential trace elements. Biomed. Res. Int. 2014, 513725.

33. Yakoob, J., Jafri, W., Abid, S., 2003. Helicobacter pylori infection and micronutrient deficiencies. World J. Gastroenterol. 9, 2137. 